\title{
Theoretical evaluation of electroanalitical determination of diazoline (mebhydrolin) on a polymer electrode
}

\author{
Volodymyr V. Tkach ${ }^{1,2}$, Marta V. Kushnir ${ }^{1}$, Yana G. Ivanushko ${ }^{1,3}$, Sílvio C. de Oliveira2 ${ }^{2}$ \\ Olga V. Luganska ${ }^{4}$, Petro I. Yagodynets ${ }^{1}$, Zholt O. Kormosh ${ }^{5}$ \\ ${ }^{1}$ Yuriy Fedkovich Chernivtsi National University, 2 Kotsiubynsky St., Chernivtsi, 58012, Ukraine \\ ${ }^{2}$ Universidade Federal de Mato Grosso do Sul, Ave. Sen. Felinto. Müller, 1555, C/P. 549, 79074-460, Campo Grande, MS, Brazil \\ ${ }^{3}$ Bukovinian State Medical University, 9 Teatralna Sq., Chernivtsi, 58000, Ukraine \\ ${ }^{4}$ Zaporizhzhya National University, 66 Zhukovskogo St., Zaporizhzhya, 69600, Ukraine \\ ${ }^{5}$ Lesya Ukrainka Eastern European National University, 13 Volya Ave., Lutsk, 43025, Ukraine
}

\begin{abstract}
Mebhydrolin, the active substance of diazoline, is a histamine H1-blocker that possesses the anti-allergic, anti-pruritic, antioxidative properties as well as weak sedative effect. It is used to treat diseases and pathological conditions. Its long-term and excessive use leads to different side effects and complications such as granulocytopenia, neutropenia, dyscrasia, and granulocytosis. That is why the development of effective methods for determining the concentration of this drug is vital. There are no reports to date available on the electrochemical determination of diazoline (mebhydrolin). Based on the structural characteristics of the molecule it can be concluded that it is an electroactive compound. Its oxidation can effectively occur on the conductive polymer layer. Moreover, the electrochemical behavior of the drug promises to be very interesting, as it is developed by a complicated mechanism. In this work, the electrochemical determination of a mebhydrolin concentration on the leading polymer was studied from a theoretical point of view. The polymerization and the reactions sequences was describe by a mathematical model, which was derived and analyzed using linear stability theory and bifurcation analysis. From the model analysis we concluded that: a). The polymer electrode promotes an electrooxidation of mebhydrolin and the system is electroanalytically effective. The relationship between the electrochemical parameter (the current) and the concentration of nitrite is described and it is linear in nature. Therefore, the analytical signal can be easily interpreted. b). The electroanalytical process occurs in the diffusion mode at low concentrations of the analyte and in the adsorption mode at high concentration. c). The oscillatory behavior of this system is possible. It is caused by the effects of the electrochemical stage on DEL as well as also by surface instabilities.
\end{abstract}

Keywords: chemically modified electrodes, mebhydrolin, conductive polymers, electrochemical sensors, steady stationary state.

\section{Introduction}

Diazoline (mebhydrolin) is an anti-allergic drug [1-6], a blocker of histamine H1-receptors, that possesses antiallergic, anti-pruritic, antioxidative, and weak sedative effect. It is used to treat diseases and pathological conditions such as hay fever, urticaria, eczema, itchy skin,

\begin{tabular}{ll}
\hline Received: & 24.04 .2020 \\
Revised: & 13.05 .2020 \\
Accepted: & 28.05 .2020 \\
Published online: & 30.06 .2020 \\
\hline
\end{tabular}

* Corresponding author. Tel.: +380-50-640-0359;

e-mail: nightwatcher2401@gmail.com (V. V. Tkach)

ORCID: 0000-0001-7696-0954 allergic rhinitis, allergic conjunctivitis, skin reaction after insect bites, bronchial asthma (as part of combination therapy).

Nevertheless, diazoline is a toxic drug, long-term and excessive use of which leads to side effects [7-12] and even complications such as granulocytopenia, neutropenia, dyscrasia, and agranulocytosis. Diazoline is contraindicated in cases of angle-closure glaucoma and prostate hypertrophy. The level of ecotoxicity of the drug is high, which includes aquatic organisms. Both the positive and negative effects of the drug are dose-dependent. Therefore, the development of effective methods for determining the concentration of this drug is without a doubt an urgent task [13-16].

(C) Tkach V. V. et al. This is an open-access article distributed under the terms of the Creative Commons Attribution License, which permits unrestricted use, distribution, and reproduction in any medium, provided the original author and source are credited. 
There are no reports to date on the electrochemical determination of mebhydrolin. Base on the structural characteristics of the molecule it can be concluded that it is an electroactive substance that can be effectively oxidized on the conductive polymeric layer. However, the development of new electroanalytical systems is always associated with solving certain problems such as:

- uncertainty about the mechanism of electrochemical action of the electrode modifier with analyte and its role in the electroanalytical system;

- possibility of electrochemical instabilities (oscillatory and monotonic) characteristic of electrosynthesis and electrooxidation of small organic molecules (including electropolymerization of heterocyclic compounds, which produces polymer coatings) [17-22].

These problems can be solved at the stage of sensor development if the experimental tests are preceded by $a$ priori theoretical mechanistic study of the electroanalytical system. It will include the development and analysis of a mathematical model that would adequately describe the electroanalytical system. Thus, the main purpose of this paper is a theoretical description of the electrochemical system for the determination of mebhydrolin at the polymer electrode. In order to achieve the goal, you need to achieve intermediate objectives, namely:

- to present the sequence of chemical and electrochemical transformations that leads to the appearance of the analytical signal and, therefore, form the basis of the electroanalytical process;

- to develop a mathematical model that would adequately describe the behavior of this system. A mathematical model should consider reaction sequences and physical processes that accompany them;

- to analyze model, and find the conditions of a steadystate stability (and, accordingly, the most efficient operation of the sensor and the best interpreted analytical signal), as well as oscillatory and monotonic instability;

- to compare the behavior of this system with similar ones [23-25].

\section{The system and its model}

Electrochemical oxidation of diazoline occurs via a radical mechanism with the expulsion of equal amounts of electrons and protons - either by the intramolecular mechanism, with the formation of a condensed indole derivative, or intermolecularly, forming a dimer; further polymerization, although theoretically possible, is hampered by the steric factor (although the polymer substrate on the surface, in general, promotes polymerization) [19]. In this case, the transfer of electrons and protons occurs through the polymer layer (Figure 1), with the radical centers of which (if any) can also recombine.<smiles>CN1CCc2c(c3ccccc3n2Cc2ccccc2)C1</smiles><smiles>C[PbH2]</smiles><smiles>CN1CCc2c(c3cccc4c3n2Cc2ccccc2-4)C1</smiles><smiles>CN1CCc2c(c3ccccc3n2Cc2ccccc2)C1</smiles><smiles>C[PbH2]</smiles><smiles></smiles>

Figure 1. Possible ways of electrochemical oxidation of diazoline (mebhydrolin). 

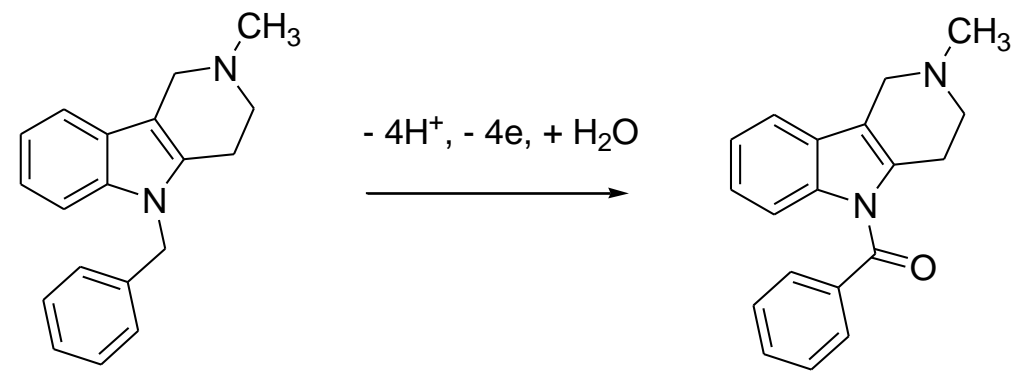

Figure 2. Oxidation of the methylene group to the carbonyl group in diazoline (mebhydrolin).

A slightly higher electrode potentials in aqueous solutions, alkaline environment, and the presence of electrode's modifiers might lead to the oxidation of the methylene group with the formation of the corresponding secondary alcohol and then ketone (Figure 2).

This paper presents electrochemical determination of diazoline at the polymer electrode and the method described in Figure 2 will not be considered (this will be the subject of one of our next works). We will limit ourselves to electrooxidation that is described in Figure 1.

In the simplest case an electroanalytical process in a neutral medium using a potentiostatic mode (amperometry) we consider three variables:

c - the concentration of diazoline in the near-surface layer;

$\theta$ - the degree of filling of the electrode's surface with diazoline;

$\mathrm{p}$ - the degree of filling of the electrode's surface with the polymer in a modified form.

To simplify the calculations, we assume that the reaction mixture is stirred vigorously (and we can neglect the convective flow) and the background electrolyte is in an excess (so that we can neglect the migration flow). We also assume that the concentration distribution of substances in the near-surface layer is linear, and the thickness of the layer itself is constant, equal to $\delta$.

We can show that the behavior of this system is described by a system of differential equations (1):

$$
\left\{\begin{array}{l}
\frac{\mathrm{dc}}{\mathrm{dt}}=\frac{2}{\delta}\left(\frac{\Delta}{\delta}\left(c_{0}-c\right)-r_{-1}-r_{1}\right) \\
\frac{d \theta}{d t}=\frac{1}{G}\left(r_{1}-r_{-1}-r_{21}-r_{22}-r_{23}\right) \\
\frac{d p}{d t}=\frac{1}{P}\left(r_{21}+r_{22}+r_{23}-r_{3}\right)
\end{array}\right.
$$

wherein $\Delta$ is the diffusion coefficient, $\mathrm{c}_{0}$ is its concentration in the thickness of the solution, $G$ and $P$ are the maximum surface concentrations of diazoline and modified polymer, respectively, and the parameters $r$ are the rates of adsorption $\left(\mathrm{r}_{1}\right)$, desorption $\left(\mathrm{r}_{-1}\right)$ and chemical reactions, which can be calculated as:

$$
\begin{aligned}
& r_{1}=k_{1} c(1-\theta) \exp (\alpha \theta) \\
& r_{-1}=k_{-1} \theta \exp (-\alpha \theta) \\
& r_{21}=k_{22} \theta(1-p) \exp (\beta \theta) \\
& r_{22}=k_{22} \theta(1-p) \exp (\beta \theta) \\
& r_{23}=k_{23} \theta(1-p) \exp (\beta \theta) \\
& r_{3}=k_{3} p \exp \left(\frac{n F \varphi_{0}}{R T}\right)
\end{aligned}
$$

wherein the parameters $\mathrm{k}$ are the specific rates of the corresponding processes, $\alpha$ is a variable describing the surface interaction of adsorbed diazoline particles, $\beta$ is a variable describing the interaction of diazoline molecules with the surface layer, $\mathrm{n}$ is the number of electrons transferred at the electrochemical stage, $\mathrm{F}=\mathrm{N}_{\mathrm{A}} * \mathrm{e}$ is the Faraday number, $\varphi_{0}$ - potential-jump relative to the potential of zero charges, R - universal gas constant, $\mathrm{T}$ - absolute temperature in the system.

\section{Results and discussion}

To study the behavior of electrochemical determination of diazoline at the polymer electrode, we analyze the system of differential equations (1) given the algebraic relations (2-7), by the methods of linear stability theory. Stationary elements of the Jacobi functional matrix would be written as:

$$
\left(\begin{array}{lll}
a_{11} & a_{12} & a_{13} \\
a_{21} & a_{22} & a_{23} \\
a_{31} & a_{32} & a_{33}
\end{array}\right)
$$




$$
\begin{aligned}
& a_{11}=\frac{2}{\delta}\left(-\frac{\Delta}{\delta}-k_{1}(1-\theta) \exp (\alpha \theta)\right) \\
& a_{12}=\frac{2}{\delta}\left(k_{-1} \exp (-\alpha \theta)-\alpha k_{-1} \theta \exp (-\alpha \theta)-k_{1}(1-\theta) \exp (\alpha \theta)+k_{1} c \exp (\alpha \theta)-\alpha k_{1}(1-\theta) c \exp (\alpha \theta)\right) \\
& a_{13}=0 \\
& a_{21}=\frac{1}{G}\left(k_{1}(1-\theta) \exp (\alpha \theta)\right) \\
& a_{22}=\frac{1}{G}\left(\begin{array}{l}
-k_{-1} \exp (-\alpha \theta)+\alpha k_{-1} \theta \exp (-\alpha \theta)-k_{1}(1-\theta) \exp (\alpha \theta)-k_{1} c \exp (\alpha \theta)+\alpha k_{1}(1-\theta) c \exp (\alpha \theta)- \\
-k_{21}(1-p) \exp (\beta p)-k_{22}(1-p) \exp (\beta p)-k_{23}(1-p) \exp (\beta p)
\end{array}\right) \\
& a_{23}=\frac{1}{G}\left(k_{21} \theta \exp (\beta p)-\beta k_{21} \theta(1-p) \exp (\beta p)+k_{22} \theta \exp (\beta p)-\beta k_{22} \theta(1-p) \exp (\beta p)+k_{23} \theta \exp (\beta p)-\beta k_{23} \theta(1-p) \exp (\beta p)\right) \\
& a_{31}=0 \\
& a_{32}=\frac{1}{P}\left(k_{21}(1-p) \exp (\beta p)+k_{22}(1-p) \exp (\beta p)+k_{23}(1-p) \exp (\beta p)\right) \\
& a_{33}=\frac{1}{P}\left(\begin{array}{l}
-k_{21} \theta \exp (\beta p)+\beta k_{21} \theta(1-p) \exp (\beta p)-k_{22} \theta \exp (\beta p)+\beta k_{22} \theta(1-p) \exp (\beta p) \\
-k_{23} \theta \exp (\beta p)+\beta k_{23} \theta(1-p) \exp (\beta p)-k_{3} \exp \left(\frac{n F \varphi_{0}}{R T}\right)-\xi k_{3} p \exp \left(\frac{n F \varphi_{0}}{R T}\right)
\end{array}\right)
\end{aligned}
$$

Figure 3. The series of Equations 10-17.

wherein: (see Figure 3).

Considering the expressions (9), (13), and (17), we can see that in the main diagonal of the Jacobi matrix several elements can describe the positive feedback. Apart from the element $-\xi k_{3} p \exp \left(\frac{n F \varphi_{0}}{R T}\right)>0$, wherein if $\xi<0$, which describes the effects on the DEL (double electric layer) capacity of the electrochemical oxidation of the modified polymer, the element can also be positive $\alpha k_{-1} \theta \exp (-\alpha \theta)>0 \alpha k_{1}(1-\theta) c \exp (\alpha \theta)>0$ i, if $\alpha>0$, and also $\quad \beta k_{21} \theta(1-p) \exp (\beta p), \quad \beta k_{22} \theta(1-p) \exp (\beta p)$, $\beta k_{23} \theta(1-p) \exp (\beta p)$, positive when $\beta>0$, describing surface instabilities caused by the attraction of adsorbed diazoline molecules among themselves and with the polymer surface. This means that the Hopf bifurcation and the oscillatory behavior described by it are possible, and they are more probable than in similar systems [23-25]. As will be shown below, the oscillatory behavior will be observed outside of determination limit and will have little effect on the electroanalytical properties of the material.
To avoid the emergence of cumbersome expressions in the analysis of the determinant of Jacobian, we introduce new variables, so that the determinant would be written as:

$$
\frac{2}{G P}\left|\begin{array}{ccc}
-\kappa_{1}-\Xi & \Lambda & 0 \\
\Xi & -\Lambda-\Omega & \mathrm{K} \\
0 & \Omega & -\mathrm{K}-\Pi
\end{array}\right|
$$

The criterion for the stability of the steady-state is the socalled Rauss-Hurwitz criterion. We can show that for trivariate systems it reduces to the inequality - Det $\mathrm{J}>0$, or, consequently, Det $\mathrm{J}<0$. By revealing the determinant of the matrix and applying to it the inequality that follows from the criterion, we can obtain the condition of stability of the steady-state, written as:

$$
-\kappa_{1}(\Lambda \mathrm{K}+\Lambda \Pi+\Omega \Pi)-\Xi \Omega \Pi<0
$$

This condition is guaranteed to be satisfied if the parameter $\mathrm{j}$ acquires positive values (which, in most cases, is observed). Thus, the steady-state is stable in a fairly wide 
range of parameters, which from an electroanalytical point of view will mean that the system is electroanalytical efficient because in it the relationship between electrochemical parameter (in this case, current) and nitrite concentration is linear and the analytical signal is easily interpreted in a wide range of parameters. Also, the form of inequality (19) indicates that the electroanalytical process occurs in the diffusion mode at low concentrations of the analyte and the adsorption mode at large.

The limit of determination is determined by the implementation of monotonic instability, which corresponds to the implementation of the saddle-node bifurcation, the point of which separates stable steady states from unstable states. The condition for its occurrence for this system is as follows:

$$
-\kappa_{1}(\Lambda \mathrm{K}+\Lambda \Pi+\Omega \Pi)-\Xi \Omega \Pi=0
$$

In the case of a modification of the polymer surface with an inorganic material, the role of the active substance is assumed by this material. The polymer remains the mediator function of the electrochemical process, which changes the behavior of the system, expanding the range of electroanalytical efficiency of the process. This system will be considered by us in the following works.

\section{Conclusions}

Theoretical analysis of determining the concentration of diazoline at the polymer electrode demonstrates that:

- the polymer electrode promotes electrooxidation of diazoline, and the system is electroanalytical effective, because in it the relationship between the electrochemical parameter (in this case, the current) and the concentration of nitrite is linear, and the analytical signal is easily interpreted;

- the electroanalytical process occurs in the diffusion mode at low concentrations of the analyte and in the adsorption mode at large ones;

- oscillatory behavior in this system is possible and it is caused not only by the effects of the electrochemical stage on DEL but also by surface instabilities.

\section{Notes}

\section{The authors declare no conflict of interest.}

Author contributions. The manuscript was written through contributions of all authors. All authors have given approval to the final version of the manuscript.

\section{References}

1. Wu, B.; Wang, H. L.; Cee V. J., et al. Discovery of 5-(1H-indol-5 yl)-1,3,4-thiadiazol-2-amines as potent PIM inhibitors. Bioorg. Med. Chem. Lett. 2015, 15, 775-780.

2. Schoor, J. V. Antihistamines : a brief review : clinical. Prof. Nurs. Today 2012, 16, 16-21.
3. McKenna, K. E.; McMillan, J. C. Exacerbation of psoriasis, liver dysfunction and thrombocytopenia associated with mebhydrolin. Clin. Exp. Dermatol. 1993, 18, 131-132.

4. Waitzinger, J.; Lenders, H.; Pabst G., et al. Three explorative studies on the efficacy of the antihistamine mebhydroline (Omeril). Int. J. Clin. Pharm. Ther. 1995, 33, 373-383.

5. Croset, S. C. J. Drug repositioning and indication discovery using description logics. Ph.D. Thesis, Darwin College, University of Cambridge, 2004.

6. Möhrle, H.; Rohn, C.; Westle, G. Indole cleavage with mebhydroline by sodium periodate - Part 2. Mechanism of the dilactam formation. Die Pharmazie, An Int. J. Pharm. Sci. 2006, 61, 391-399 (in German).

7. Edoute, Y.; Nagler, A.; Brenner, B. Agranulocytosis Associated With Mebhydrolin Napadisylate (Incidal). Harefuah 1984, 106, 208-209 (in Hebrew).

8. Guzzetti, R.; Saggiorato, F. Studio dell'efficacia e tollerabilita della mebidrolina in confront a dimetindene maleate. Clin. Ter. 1986, 116, 109-114 (in Italian).

9. Hafeez, Z. H.; Antihistamines and Their Role in Dermatology. J. Pak. Med. Assoc. 1996, 46, 1-6.

10. Mebhydrolin napadisilate, $\mathrm{CID}=22529$, In PubChem Database. National Center for Biotechnology Information. [Internet]. Available from: $\quad$ https://pubchem.ncbi.nlm.nih.gov/compound/Diazoline\# section=Depositor-Provided-PubMed-Citations (accessed on April 24, 2020).

11. Mebhydrolin. EC nimber: 208-364-4, In ECHA Database. [Internet]. Available from: https://euon.echa.europa.eu/lt/web/guest/registrationdossier/-/registered-dossier/22142/11 (accessed on April 24, 2020).

12. Young, C. A. R.; Forrest, P.; Deveridge, S. F.; Gates, R. B.; Vincent, P.C. Abstract: Mebhydrolin induced agranulocytosis. Aust. N. Z. J. Med. 1982, 12, 173-176.

13. Nerdy, N. Development and validation of ultraviolet spectrophotometric method for determination of mebhydrolin napadisylate in tablet preparations. Asian J. Pharm. Clin. Res. 2017, 10, 367-372.

14. Wulandari, L. Determination and validation of mebhydroline napadisylate in tablets by HPLC. Indo. J. Chem. 2008, 8, 377-379.

15. Wulandari, L.; Evaluation of re-used HPTLC plate for qualitative abd quantitative analysis. Indo. J. Chem. 2006, 6, 338-340.

16. Suhadi, R.; Linawati, Y.; Wulandari, E. T.; Viriginia, D. M.; Setiawan, C. H. The metabolic disorders and cardiovascular risk among lower socioeconomic subjects in Yogyakarta-Indonesia. Asian J. Pharm. Clin. Res. 2017, 10, 367-372.

17. Pearlstein, A. J.; Johnson, J. A. Global and Conditional Stability of the Steady and Periodic Solutions of the Franck-FitzHugh Model of Electrodissolution of $\mathrm{Fe}$ in $\mathrm{H}_{2} \mathrm{SO}_{4}$. J. Electrochem. Soc. 1991, 136, 1290-1299.

18. Rahman, S. U.; Ba-Shammakh, M. S. Thermal effects on the process of electropolymerization of pyrrole on mild steel. Synth. Met. 2004, 140, 207-223.

19. de Andrade, V. M. Confecção de biossensores através da imobilização de biocomponentes por eletropolimerização de pirrol, M.S. Thesis, Universidade Federal de Mato Grosso do Sul, Porto Alegre, 2006 (In Portuguese).

20. Tosar Rovira, J. P. Estudio de la inmovilización de oligonucleótidos a elétrodos modificados de oro:polipirrol, y detección electroquímica de secuencias complementarias, M.S. Thesis, Universidad de la República, Montevideo, 2008 (In Spanish).

21. Das, I.; Goel, N.; Gupta, S. K.; Agrawal, N.R. Electropolymerization of pyrrole: Dendrimers, nano-sized patterns and oscillations in potential in presence of aromatic and aliphatic surfactants. $J$. Electroanal. Chem. 2012, 670, 1-10.

22. Singh, R. Prospects of Organic Conducting Polymer Modified Electrodes: Enzymosensors. Int. J. Electrochem. 2012, N. 502707.

23. Tkach, V.; Swamy, B. K.; Ojani, R. et. al. El Mecanismo de la Oxidación de Omeprazol Sobre el Electrodo de Carbono Vitroso, Modificado por Polializarina, y Su Descripción Matemática. Orbital Elec. J. Chem. 2015, 7, 1-4 (In Spanish).

24. Tkach, V.; Swamy, B. K.; Ojani R. et. al. O comportamento de paracetamol durante a sua oxidação eletrocatalítica sobre poli(azul da anilina) e a sua descrição matemática. Rev. Colomb. Cien. Quím. Farm. 2015, 44, 148-161 (In Portuguese).

25. Tkach, V.; Ojani, R.; Nechyporuk, V.; Yagodynets, P. The mathematical study of the electrochemical nitrite sensorbased on poly(p-aminoacetanilide). Rev. Fac. Ing. UCV. 2015, 30, 181-188 (In Portuguese). 


\title{
Теоретична оцінка електроаналітичного визначення діазоліну (мебгідроліну) на полімерному електроді
}

В. В. Ткач ${ }^{1,2 *}$, М. В. Кушнір ${ }^{1}$, Я. Г. Іванушко ${ }^{1,3}$, С. С. де Олівейра ${ }^{2}$, О. В. Луганська ${ }^{4}$, П. І. Ягодинець ${ }^{1}$, Жолт О. Кормош ${ }^{5}$

\author{
${ }^{1}$ Чернівецький національний університет імені Юрія Федьковича, вул. Коцюбинського, 2, Чернівиі, 58012, Україна \\ ${ }^{2}$ Федеральний університет штату Мату-Гросу-ду-Сул, просп. Сенадора Філінто Мюллера, 1555, Кампу-Гранді, Мату-Гросу-ду-Сул, \\ 79074-460, Бразилія \\ ${ }^{3}$ Буковинський державний медичний університет, пл. Театральна, 2, Чернівці, 58002, Украӥна \\ ${ }^{4}$ Запорізький національний університет, вул. Жуковського, 66, Запоріжжся, 69600, Украйна \\ ${ }^{5}$ Східноєвропейський національний університет імені Лесі Украӥнки, просп. Волі, 13, Луиьк, 43025, Украӥна
}

Резюме: У даній роботі з теоретичної точки зору розглядається можливість електрохімічного визначення концентрації мебгідроліну (діюча речовина препарату діазоліну) на аноді, модифікованому провідним полімером . Мебгідролін є одним із широко застосованих антигістамінних препаратів. Його застосовують при таких патологічних станах як сінна лихоманка, кропив'янка, екзема, шкірний свербіж, алергічний риніт, алергічний кон'юнктивіт, шкірна реакція після укусу комахи, бронхіальна астма. Незважаючи на це, мебгідролін проявляє ряд побічних ефектів і протипоказаний до ряду категорій населення. В будь-якому разі, його дія $\epsilon$ сильно залежною від дози. Тому його визначення $\epsilon$ дійсно актуальним. Наразі не відомо жодної роботи, присвяченої електрохімічному визначенню мебгідроліну. Однак, з огляду на будову молекули, можна зробити висновок про те, що це електроактивна речовина, окиснення якої може ефективно відбутися на провідному полімерному шарі. Мало того, як похідне індолу, мебгідролін може бути підданим електрополімеризації, яка може супроводжуватися внутрішньомолекулярною циклізацією. Відтак, з огляду на «розгалуженість» механізму, а також можливість появи електрохімічних нестійкостей (осциляторна, монотонна), a priori теоретичне механістичне дослідження електроаналітичної системи, яке включатиме розробку та аналіз математичної моделі, що б адекватно описувала електроаналітичну систему є дійсно важливим. Для даного процесу було розроблено триваріантну математичну модель балансових диференціальних рівнянь, що включає обидва сценарії окиснення мебгідроліну з відщепленням протонів та електронів. Аналіз моделі показує, що: а). Полімерний електрод сприяє електроокисненню діазоліну, а система електроаналітично ефективна, оскільки в ній залежність між електрохімічним параметром (в даному випадку, струмом) і концентрацією нітриту є лінійною, а аналітичний сигнал легко інтерпретується. б). Електроаналітичний процес відбувається в дифузійному режимі за малих концентрацій аналіту і в адсорбційному за великих. в). Осциляторна поведінка в даній системі можлива і вона спричиняється не лишень впливами електрохімічної стадії на ПЕШ, а й поверхневими нестійкостями.

Ключові слова: хімічно модифікований електрод, мебгідролін, провідні полімери, електрохімічні сенсори, стійкий стаціонарний стан. 


\section{TВOЯ УСПIШHA KAP'GPA В УКРАÏHI}

Науково-виробниче підприємство «Єнамін» (м. Київ) - найбільша українська організація, що займається дослідженням і синтезом сполук для потреб фарма- та агроіндустрії, а також надає послуги в сфері розробки новітніх лікарських засобів та ранніх доклінічних досліджень. За 29 років існування Єнамін став світовим лідером у своїй галузі, активно співпрацюючи з такими відомими фармацевтичними компаніями як Abbvie, Bayer, GlaxoSmithKline, Merck, Pfizer та інші. У компанії сформований злагоджений колектив науковців, до складу якого входять 140 докторів і кандидатів наук та понад 600 кваліфікованих спеціалістів - професіоналів у галузі органічної та медичної хімії, біохімії, клітинної біології, in vitro та in vivo фармакології. Щорічно науковий колектив Енаміну публікує десятки статей у найпрестижніших фахових виданнях.

\section{ДОЛУЧАЙСЯ ДО НАШОӤ КОМАНДИ!}

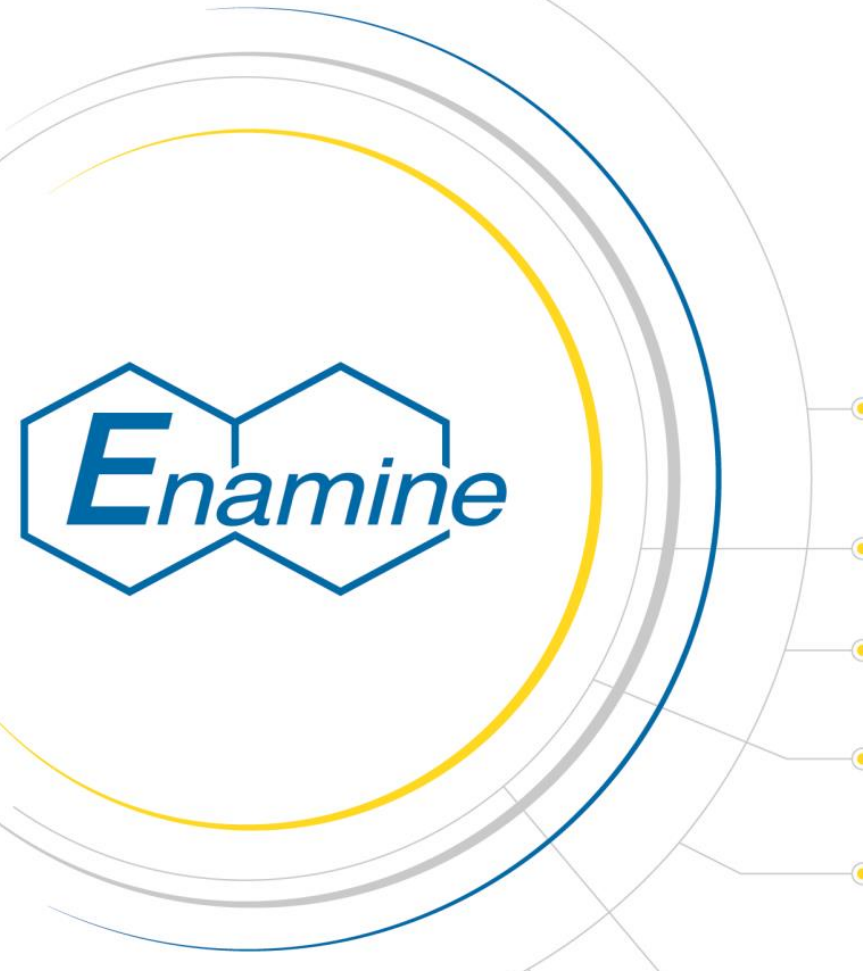

\section{НАШI ПЕРЕВАГИ:}

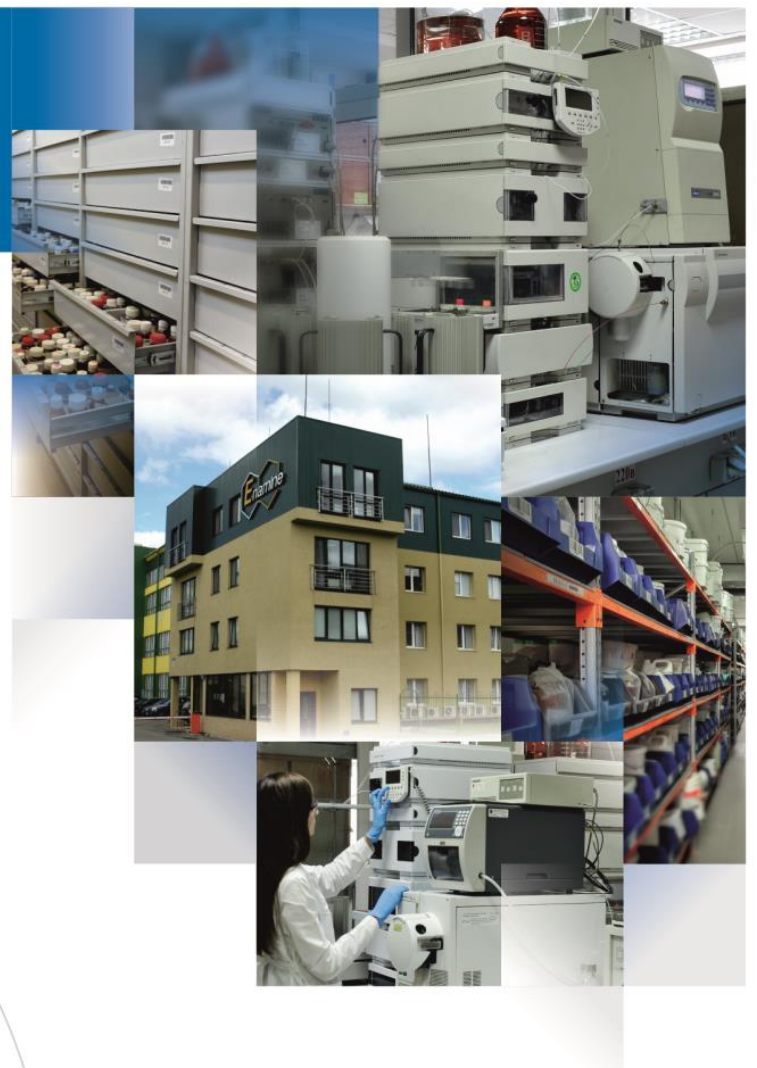

\section{НАШІ РЕСУРСИ:}

100 синтетичних лабораторій

оснащені найсучаснішим

в Україні обладнанням

Найбільша у світі колекція реактивів (понад 225 тисяч сполук)

\section{4 власні ЯМР-спектрометри}

(400 і 500 МГц)

\section{0 препаративних та 20 аналітичних хроматографів}

\section{Доступ до літературних баз даних}

безпосередньо з робочих місць, що дозволяє оперативно отримувати посилання та статті з багатьох наукових періодичних видань

\section{Власна склодувна майстерня}

\section{Гідна заробітна платня}

\section{Власний Центр Фармакологічного Скринінгу}

\section{Надання житла}

Власні комфортабельні гуртожитки в м. Бровари (за 30 хвилин від місця роботи).

\section{Кар'єрне зростання}

Навіть, почавши простим лаборантом, маєте можливість вже за кілька років очолити лабораторію або відділ.

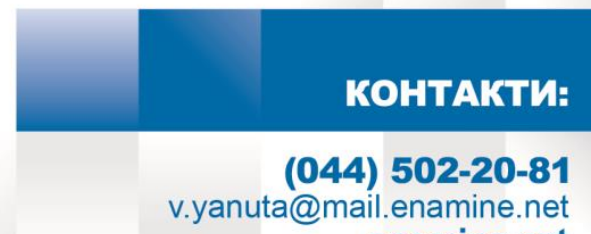

Навчання та наукова кар'єра

Завдяки гнучкому графіку легко поєднувати роботу в компанії з навчанням в університеті. 